\title{
Implementasi Sistem Informasi Manajemen Akademik Berbasis Teknologi Informasi dalam Meningkatkan Mutu Pelayanan Pembelajaran di SMK
}

\author{
${ }^{1}$ Annisa Mayasari*, 2 Yuli Supriani, ${ }^{3}$ Opan Arifudin \\ 1STAI Sabili Bandung, Indonesia \\ 2IAI Agus Salim Lampung, Indonesia \\ ${ }^{3}$ Universitas Islam Nusantara Bandung, Indonesia \\ E-mail: *annisamayasari020@gmail.com
}

Article Info
Article History
Received: $2021-07-12$
Revised: $2021-08-15$
Published: $2021-09-11$

Keywords:

Management; Information Systems; Quality of service; Learning.

\begin{abstract}
The development has a goal to create a productive, creative, innovative, and affective society. A cultured society where where the educational service management is served efficiently and effectively to its costumer. Therefore, an IT based school management information system should be implemented in a school. The decision makers of education section has an important role in education management information system, especially in planning, supervising, monitoring and evaluating. Moreover, this research is aimed to discuss further about the implementation of management information system (SIM) to improve the teaching-learning service quality in SMK. The qualitative approach is used in this research and descriptive method is a method that is used in this research. The population of this research is SMK N 2 and SMK N 6 Bandung. The objective of this research is to figure out how is the planning, implementation and the evaluation of academic management information system in improving teachinglearning service quality in SMK. Based on the result of the research, it shows that the planning of SIM academic is good enough, the implementation of SIM academic is conducted by the headmaster and the SIM academic team and the result is good enough. Althought, the information channel does not run to its maximum potential.
\end{abstract}

\begin{tabular}{l}
\hline Artikel Info \\
\hline Sejarah Artikel \\
Diterima: 2021-07-12 \\
Direvisi: 2021-08-15 \\
Dipublikasi: 2021-09-11
\end{tabular}

Kata kunci:

Manajemen;

Sistem informasi;

Kualitas layanan;

Pembelajaran.

\begin{abstract}
Abstrak
Pembangunan bertujuan untuk mewujudkan masyarakat yang produktif, kreatif, inovatif, dan afektif. Masyarakat yang berbudaya dimana manajemen pelayanan pendidikan terlayani secara efisien dan efektif kepada pelanggannya. Oleh karena itu, sistem informasi manajemen sekolah berbasis IT harus diterapkan di sebuah sekolah. Pengambil keputusan bagian pendidikan memiliki peran penting dalam sistem informasi manajemen pendidikan, terutama dalam perencanaan, pengawasan, pemantauan dan evaluasi. Selain itu, penelitian ini bertujuan untuk membahas lebih lanjut tentang penerapan sistem informasi manajemen (SIM) untuk meningkatkan kualitas layanan belajar-mengajar di SMK. Pendekatan kualitatif digunakan dalam penelitian ini dan metode deskriptif adalah metode yang digunakan dalam penelitian ini. Populasi dalam penelitian ini adalah SMK N 2 dan SMK N 6 Bandung. Penelitian ini bertujuan untuk mengetahui bagaimana perencanaan, pelaksanaan dan evaluasi sistem informasi manajemen akademik dalam meningkatkan kualitas layanan belajar mengajar di SMK. Berdasarkan hasil penelitian menunjukkan bahwa perencanaan SIM akademik sudah cukup baik, pelaksanaan SIM akademik dilakukan oleh kepala sekolah dan tim akademik SIM dan hasilnya cukup baik. Meski demikian, saluran informasi belum berjalan secara maksimal.
\end{abstract}

\section{PENDAHULUAN}

Berubahnya Kurikulum 2006 menjadi Kurikulum 2013 merupakan wujud pengembangan pelaksanaan sistem pendidikan di Indonesia yang memiliki tujuan yaitu membentuk pribadi bangsa yang produktif, kreatif, inovatif dan afektif sebagai modal untuk membangun sebuah bangsa yang beradab. Oleh karena itu setiap organisasi mencoba untuk menerapkan sistem atau teknologi informasi agar dapat meningkatkan efisiensi dan efektifitas dalam proses pengelolaan organisasinya. Dimana dalam memberikan layanan pendidikan kepada pelanggannya harus senantiasa ditingkatkan efisiensi dan efektivitas pengelolaannya. Menurut (Arifudin, 2021) efisiensi dan efektivitas pada layanan jasa merupakan bagian dari strategi dalam memberikan pelayanan yang maksimal pada pelanggan, Penerapan sistem teknologi informasi akan bermanfaat jika penerapannya 
sesuai dengan tujuan, visi dan misi organisasi dengan menetapkan strategi bisnis dan strategi sistem teknologi informasi, dalam prakteknya penerapan atau implementasi SIM pendidikan di sebuah organisasi pendidikan diperlukan analisis dan perencanaan strategis disesuaikan dengan kondisi internal dan eksternal organisasi. Menurut (Nadeak, 2020) bahwa dalam memanfaatkan pendekatan teknologi dalam sebuah organisasi diperlukan desain analisis dalam mengoptimalkan peran teknologi. Setelah itu dilakukan pemilihan model sistem informasi manajemen yang sesuai dengan kebutuhan organisasi tersebut. Kemudian efektivitas implementasi SIM tersebut harus di evaluasi terhadap tujuan, visi dan misi organisasi tersebut,

penerapan Sistem Informasi Manajemen yang tidak kalah pentingnya dalam meningkatkan mutu pelayanan akademik sekolah sehingga menjadi indikator utama bahwa sekolah itu efektif, beberapa penelitian telah dilakukan guna menganalisis kebutuhan penerapan SIM. Acep Irham Gufroni (2011) dalam penelitiannya yang berjudul "Information systems Strategic Planning at the Siliwangi University Tasikmalaya" menyatakan bahwa penggunaan metode value chain analysis dan SWOT analysis dapat digunakan guna menganalisis kebutuhan penerapan SIM di Universitas Siliwangi Tasikmalaya. Penelitian lainnya dilakukan Triwiyono (2012) dalam penelitiannya yang berjudul "Implementasi Sistem Informasi Manajemen Akademik berbasis Teknologi Informasi Di Sekolah Dasar" menyatakan bahwa penggunaan metode value chain analysis dan SWOT analysis dapat digunakan guna menganalisis kebutuhan penerapan SIM di Sekolah Dasar Islam Terpadu Fitrhah Insani. Sehingga berdasar penelitian yang telah dilakukan bahwa dalam implementasi system informasi manajemen di Lembaga pendidikan dibutuhkan analisis terkait pemanfaatannya.

Dalam dunia pendidikan pengelolaan dan penggunaan sistem informasi manajemen pendidikan tidak dapat dipisahkan dari aktivitas pendidikan itu sendiri dimana itu terkait proses belajar mengajar maupun dari awal siswa dan guru itu masuk kedalam sekolah dan keluar juga dari sekolah itu. Meningkatnya ilmu pengetahuan dan teknologi terutama dalam bidang komputerisasi telah menunjukkan bahwa perkembangan tersebut dapat membantu menyelesaikan suatu masalah pada proses penerapan sistem informasi manajemen pendidikan. Menurut
(Irwansyah, 2021) bahwa pemanfaatan teknologi informasi manajemen ini juga akan dapat mengurangi tahap proses kerja dalam organisasi, pemanfaatan dan perkem-bangan inilah yang nantinya akan dapat membantu setiap pihakpihak terkait yang dilakukan dalam suatu organisasi maupun masyarakat sekolah.

Sistem informasi manajemen sekolah dapat dikatakan berjalan apabila semua komponen sekolah dapat menggunakan dan memanfaatkan sistem itu sendiri. Menurut (Tanjung, 2020) bahwa implementasi system informasi manajemen dilihat dengan adanya fasilitas terpadu atau terintegrasi jadi satu mulai dari database peserta didik, guru, bimbingan dan konseling, kartu pelajar yang ada barcodenya, daftar hadir siswa, guru ataupun pegawai, nilai (ulangan, UTS, UAS, Try out dll) dimana rapor otomatis diprogram. Sedangkan menurut (Bairizki, 2021) sistem informasi manajemen sekolah yang baik harus terdapat aplikasi SMS gateway sistem atau biasa disebut sms smart school ini juga mudah karena dikelola sendiri oleh sekolah jadi biaya akses lebih murah dan mudah dipantau, dengan sms smart school wali siswa dapat menerima laporan otomatis dari pihak sekolah, misalnya nilai siswa, pelanggaran disiplin, pembayaran uang sekolah, data guru dan informasi sekolah transparan lainnya. Sehingga dengan hal ini menurut (Sofyan, 2020) bahwa layanan bimbingan pada siswa terus dilakukan dalam rangka menghasilkan karakter yang baik pada peserta didik.

Menurut Eti Rochaety dalam (Febrianty, 2020) bahwa dampak positif diterapkannya teknologi informasi pada organisasi pendidikan adalah kinerja organisasi lebih efisien karena teknologi informasi dapat menghapus posisi penyambung komunikasi dari dua tempat yang berkepentingan, juga menghapuskan batas waktu untuk operasi internasional. Selain itu menurut (Juhji, 2020) bahwa dampak positif system informasi manajemen bagi peserta didik atau mahasiswa bisa melaksanakan pembelajaran dengan berbasis internet yang biasa disebut dengan e-learning sehingga pembelajarannya lebih praktis dan hasil atau mutu dari pembelajarannya yang lebih praktis dan hasil atau mutu dari pembelajarannya tidak kalah bagus dengan pembelajaran klasikal.

Menurut (Tanjung, 2019) bahwa sistem informasi manajemen pendidikan merupakan perpaduan antara sumber daya manusia dan aplikasi teknologi informasi untuk memilih, menyimpan, mengolah dan mengambil kembali 
data dalam rangka mendukung kembali proses pengambilan keputusan dalam bidang pendidikan dan data-data tersebut adalah empiris atau data yang berupa fakta sebenarnya yang benar-benar ada dan dapat dipertanggung jawabkan kebenarannya. Selain itu segala kebutuhan pelaporan dari sekolah ke dinas pendidikan daerah maupun untuk kebutuhan depdiknas dapat dilakukan dengan mudah, dengan adanya sistem informasi manajemen pendidikan ini dapat membuat manajemen pendidikan menjadi lebih terkontrol dan mudah. Namun hal ini juga menjadi sebuah tantangan dalam pengelolaan system informasi manajemen terutama dalam menyediakan tenaga ahli sebagai sumber daya manusia dalam implementasi system informasi manajemen di Sekolah.

Dapat disimpulkan menurut (Arifudin, 2019) bahwa teknologi dan informasi yang berkembang cepat dengan sistem di era modern ini membawa dua dampak yaitu positif dan dampak negatif, namun, terlepas dari dampak tersebut, terlihat bahwa berbagai organisasi khususnya organisasi pendidikan menyambut dengan baik perkembangan teknologi informasi. Hal ini menurut (Arifudin, 2020) bahwa dapat dilihat dengan banyaknya sekolah ataupun universitas yang menerapkan teknologi informasi dan pihak sekolah sendiri harus mempersiapkan strategi untuk menghadapi dampak negatif atau permasalahan yang mungkin terjadi dari penerapan teknologi informasi tersebut.

Berdasarkan masalah-masalah ini perlu dilakukan penelitian lebih lanjut supaya dapat di temukan data yang valid dan sekaligus dapat ditentukan alternatif pemecahannya. Sehingga penulis mengangkat judul "Implementasi Sistem Informasi Manajemen Akademik Berbasis Teknologi Informasi Dalam Meningkatkan Mutu Pelayanan Pembelajaran Di Sekolah Menengah Kejuruan".

\section{METODE PENELITIAN}

Penelitian kompetensi manajerial kepala sekolah dalam meningkatkan kinerja guru Sekolah dasar menggunakan pendekatan kualitatif. Menurut Sugiyono dalam (Nasser, 2021) bahwa metode penelitian kualitatif adalah metode penelitian yang digunakan untuk meneliti pada kondisi obyek yangalamiah dimana peneliti adalah sebagai instrumen kunci. Dalam penelitian kualitatif memiliki karakteristik analisis tekstual atau dalam pandangan Creswell sebagaimana dikutip (Arifudin, 2018) bahwa penelitian kualitatif merupakan penelitian interpretatif, yang di dalamnya peneliti terlibat dalam pengalaman yang berkelanjutan dan terus menerus dengan para partisipan. Adapun metode dalam penelitian ini adalah deskriptif analisis.

Dalam hal pengumpulan data yang diperoleh dari berbagai sumber, latar, dan beragam cara pada penelitian ini adalah melalui studi kepustakaan, studi kepustakaan merupakan langkah awal dalam metode pengumpulan data. Studi pustaka merupakan metode pengumpulan data yang diarahkan kepada pencarian data dan informasi melalui dokumen-dokumen, baik dokumen tertulis, foto-foto, gambar, maupun dokumen elektronik yang dapat mendukung dalam proses penulisan. Menurut Sugiyono sebagaimana dikutip (Rahayu, 2020) dokumen merupakan catatan peristiwa yang sudah berlalu. Dokumen bisa berbentuk gambar tulisan, gambar, atau karya-karya monumental dari seseorang. Hal itu, sejalan dengan pendapat Creswell dalam (Rusmana, 2020) bahwa dokumen-dokumen kualitatif (qualitatif document) bisa berupa dokumen publik (misalnya koran, makalah, laporan kantor) ataupun dokumen privat (mislanya buku harian, diari, surat, e-mail).

\section{HASIL DAN PEMBAHASAN}

Berdasarkan hasil penelitian bahwa Implementasi Sistem Informasi Manajemen Akademik Berbasis Teknologi Informasi dalam Meningkatkan Mutu Pelayanan Pembelajaran di Sekolah Menengah Kejuruan dilakukan dengan tahapan perencanaan, pelaksanaan, dan evaluasi.

\section{A. Manajemen Perencanaan Sistem Informasi, Manajemen Akademik Berbasis Teknologi Informasi}

Sesuai dengan temuan dan interprestasi hasil penelitian, perencanaan pembelajaran yang dilaksanakan dan dikembangkan di kedua SMK Negeri tersebut dituangkan dalam bentuk dokumen, diantara profil sekolah, data guru, data siswa, data Tata usaha, Data Nilai, Data alumni, data prestasi siswa, materi pembelajaran dan soal-soal latihan. Penyusunan SIM Akademik ini dilaksanakan secara bersama-sama atau adanya tim khusus yang mengelola SIM Akademik tersebut, guna menghasilkan informasi yang update.

Perencanaan SIM Akademik dalam perencanaan pembelajaran ini merupakan hasil proses berfikir yang mendalam, hasil dari proses penyeleksian dari berbagai alternatif yang dianggap lebih memiliki hasil informasi yang efektif dan efisien. Melalui 
perencanaan ditetapkan terlebih dahulu yang akan dikerjakan, bagaimana mengerjakannya, apa yang harus dikerjakan, dan siapa yang mengerjakannya. Melalui perencanaan pula disusun dan ditentukan tujuan dan tindakantindakan yang harus diambil untuk menyelesaikan suatu proses implementasi SIM Akademik berbasis teknologi informasi, dengan disusunnya program perencanaan SIM Akademik berbasis teknologi informasi dalam bentuk website atau aplikasi, maka tergambarkan langkah-langkah kegiatan perencanaan Sim Akademik berbasis teknologi informasi, prinsip berlaku baik untuk sistem informasi manual, elektromekanis, maupun komputer.

\section{B. Manajemen Pelaksanaan Sistem Informasi, Manajemen Akademik Berbasis Teknologi Informasi}

Pelaksanaan Sistem informasi Manajemen Akademik berbasis teknologi informasi merupakan implementasi dari perencanaan SIM Akademik. Dalam konteks manajemen implementasi SIM Akademik menjadi sangat penting dalam pengelolaan administrasi pendidikan guna membangun peningkatan kualitas pendidikan. Penggunaan sistem informasi akademik ini dapat terlaksana dengan baik jika dilakukan secara terintegrasi dari beragai sumber potensi yang ada, sehingga diharapkan dengan pemanfaatan sistem informasi ini dapat menunjang dalam peningkatan kualitas pendidikan sehingga tujuan pendidikan yang produktif dapat tercapai.

Dalam konteks pelaksanaan SIM Akademik berbasis teknologi informasi di SMK Negeri ini tugas menggerakan dilakukan oleh kepala sekolah sebagai pemimpin instruksional, sedangkan dalam konteks petugas pelaksana Sistem Informasi manajemen dilakukan oleh Tim SIM Akademik dan instruksi kepala Tata Usaha sebagai penanggung jawab. Sebagaimana mestinya sistem informasi manajemen akademik harus terdiri dari beberapa unsur pokok yang saling berhubungan dan mempengaruhi satu sama lain. Namun demikian ada tiga syarat mutlak yang harus ada dalam pelaksanaan atau pemanfaatan sistem informasi manajemen pendidikan yaitu : a) Tersedianya sumberdaya manusia yang cukup baik, jumlah maupun kemampuannya dalam hal pelaksanaan atau pemanfaatan sistem informasi manajemen di sekolah, b)
Terbangunnya mekanisme atau prosedur pengumpul data yang teratur, sesuai kebutuhan, tepat waktu dan tersedianya instrumen pegumpul data. Baik di tingkat Dinas maupun Sekolah, harus ada mekanisme yang jelas dan pasti mengenai alur pengumpul data, termasuk siapa yang mengumpulkan data, jadewal pelaksanaan, instrumen yang digunakan, kemana atau kepada siapa data tersebut diserahkan, dan c) Tersedianya peralatan, baik perangkat keras maupun perangkat lunaknya. Perangkat keras yang diperlukan untuk membangun sebuah sistem manajemen adalah komputer, server dan jaringan internet yang spesifikasinya harus sesuai dengan kebutuhan. Sedangkan perangkat lunak yang dibutuhkan terutama program aplikasi database dan pengolahan data. (Kemendiknas, 2010)

\section{Manajemen evaluasi Sistem Informasi, Manajemen Akademik Berbasis Teknologi Informasi}

Evaluasi di SMK Negeri 2 dan SMK Negeri 6 digunakan sebagai kegiatan untuk memberikan pertimbangan mengenai nilai dan arti sesuatu yang dipertimbangkan (evaluation). Evaluasi yang dikembangkan di kedua SMK ini mempunyai dua karakteristik, yaitu evaluasi sebagai suatu proses dan evaluasi yang berhubungan dengan pemberian nilai atau arti. Sebagai suatu proses evaluasi merupakan rangkaian tindakan, evaluasi sebagai pemberian nilai mengandung arti menunjukan kualitas yang dinilai. Salah satu indikator pengelolahan manajemen sekolah berhasil adalah adanya informasi data yang akurat, tepat dan cepat.

Sistem informasi Manajemen sekolah merupakan ujung tombak dalam merealisasikan semua informasi up to date tersebut. Tentunya dengan dukungan semua sub sistem yang ada pada organisasi tersebut. Dari hasil penelitian di lapangan SIM Akademik di SMK Negeri 2 dan 6 Bandung selalu dihadapkan tantangan dan ekspektasi yang sangat besar dan berat. Kedua SMK ini sangat membutuhkan semua informasi-informasi tersebut, yang idealnya hal itu disediakan oleh pengelola unit kerja SIM sebagai pusat basis data. Meskipun pada kenyataan di lapangan semua informasi tersebut belumlah dapat terpenuhi dan dikelola dengan baik oleh pengelola Tim SIM SMK Negeri 2 dan 6 Bandung. Kenyataan yang ada semua 
informasi dan data yang mengalir di SMK Negeri 2 dan 6 Bandung bersifat Parsial, tidak utuh, tidak menyeluruh bahkan mungkin tidak up to date.

\section{SIMPULAN DAN SARAN}

\section{A. Simpulan}

Manajemen SIM Akademik Berbasis Teknologi Informasi yang dilaksanakan di SMK terdiri dari Perencanaan SIM Akademik, Pelaksanaan SIM Akademik, dan Evaluasi SIM Akademik. Perencanaan SIM Akademik dalam meningkatkan Mutu Pelayanan Pembelajaran, produk yang dihasilkan dari kegiatan perencanaan SIM Akademik meliputi Data Guru, Data Administrasi Guru, Data Jadwal dan Jam mengajar Guru, Data Nilai, Data Siswa, Data Tata Usaha, Surat Tugas, Laporan dan Data Referensi. Pelaksanaan SIM Akademik yang terjadi masih bersifat Parsial dan belum dikelola dengan baik secara maksimal oleh Tim SIM Akademik yang ada di SMK tersebut. Evaluasi SIM Akademik dilaksanakan mengacu kepada standar pengelolaan Kemendiknas terbaru bahwa sebuah sistem informasi yang baik diantaranya data dan informasi harus akurat, konsisten dan mutakhir.

\section{B. Saran}

Adapun saran yang dapat disampaikan berdasarkan pada hasil penelitian ini, yaitu sebagai berikut:

a) Optimalkan peran system informasi manajemen agara semua dokumen perencanaan di Sekolah dapat terupdate dan terakses secara tepat dan akurat.

b) Semua Sumber Daya Manusia yang terlibat dalam pelaksanaan pembelajaran (Kepala Sekolah, Tata Usaha, Guru, Siswa dan Orang Tua Siswa) dapat dengan mudah mengontrol informasi prestasi siswanya dan kemajuan sekolah secara keseluruhan.

c) Manajemen Pelayanan pembelajaran terhadap siswa lebih optimal karena tidak terbatas dalam pertemuan di kelas tapi siswa dapat mengakses informasi pembelajaran diluar pertemuan tatap muka dan kegiatan sekolah.

d) Jika sekolah dapat menerapkan sistem informasi manajemen akademik berbasis teknologi informasi dapat meningkatkan mutu pelayanan pembelajaran yang berakibat pada peningkatan prestasi belajar siswa.

\section{DAFTAR RUJUKAN}

Arifudin, O. (2018). Pengaruh Pelatihan Dan Motivasi Terhadap Produktivitas Kerja
Tenaga Kependidikan Stit Rakeyan Santang Karawang. MEA (Manajemen, Ekonomi, \& Akuntansi), 2(3), 209-218.

Arifudin, O. (2019). Manajemen Sistem Penjaminan Mutu Internal (SPMI) Sebagai Upaya Meningkatkan Mutu Perguruan Tinggi. MEA (Manajemen, Ekonomi, \& Akuntansi), 3(1), 161-169.

Arifudin, O. (2020). Psikologi Pendidikan (Tinjauan Teori Dan Praktis). Bandung : Widina Bhakti Persada.

Arifudin, 0. (2021). Manajemen Strategik Teori Dan Implementasi. Banyumas : Pena Persada.

Bairizki, A. (2021). Manajemen Perubahan. Bandung : Widina Bhakti Persada.

Febrianty, F. (2020). Kepemimpinan \& Prilaku Organisasi Konsep Dan Perkembangan. Bandung: Widina Bhakti Persada.

Irwansyah, R. (2021). Perkembangan Peserta Didik. Bandung : Widina Bhakti Persada.

Juhji. (2020). Manajemen Humas Sekolah. Bandung: Widina Bhakti Persada.

Nadeak, B. (2020). Manajemen Humas Pada Lembaga Pendidikan. Bandung: Widina Bhakti Persada.

Nasser, A. A. (2021). Sistem Penerimaan Siswa Baru Berbasis Web Dalam Meningkatkan Mutu Siswa Di Era Pandemi. Biormatika: Jurnal Ilmiah Fakultas Keguruan Dan Ilmu Pendidikan, 7(1), 100-109.

Rahayu, Y. N. (2020). Program Linier (Teori Dan Aplikasi). Bandung : Widina Bhakti Persada.

Rusmana, F. D. (2020). Pengaruh Gaya Kepemimpinan Transformasional Dan Transaksional Dengan Kinerja Karyawan BRI Syariah Subang. JURNAL MAKRO MANAJEMEN, 5(2), 157-163.

Sofyan, Y. (2020). Peranan Konseling Dosen Wali Dalam Meningkatkan Motivasi Belajar Mahasiswa Di Perguruan Tinggi Swasta Wilayah LLDIKTI IV. Jurnal Bimbingan Dan Konseling Islam, 10(2), 237-242.

Tanjung, R. (2019). Manajemen Pelayanan Prima 
Dalam Meningkatkan Kepuasan Mahasiswa Terhadap Layanan Pembelajaran (Studi Kasus di STIT Rakeyan Santang Karawang). MEA (Manajemen, Ekonomi, \& Akuntansi), 3(1), 234-242.
Tanjung, R. (2020). Pengaruh Penilaian Diri Dan Efikasi Diri Terhadap Kepuasan Kerja Serta Implikasinya Terhadap Kinerja Guru. Jurnal Ilmiah MEA (Manajemen, Ekonomi, Dan Akuntansi), 4(1), 380-391. 